IKONOMIKA: Journal of Islamic Economics and Business

Volume 3, No I (2018)

ISSN : 2527-3434 (PRINT) - ISSN: 2527-5I43 (ONLINE)

Page : 97 - 106

\title{
Bank Soundness and Sustainability-Evidence From Middle East, Indian Sub-Continent and African Banks
}

\author{
Abdul Razak Abdul Hadi ${ }^{1}$,Tulus Suryanto ${ }^{2}$, \\ Eddy Yap Tat Hiung ${ }^{3}$ \\ Universiti Kuala Lumpur Malaysia ${ }^{\mathrm{I}, 3}$, \\ Universitas Islam Negeri Raden Intan Lampung Indonesia ${ }^{2}$ \\ abdrazak@unikl.edu.my ${ }^{1}$,tulus_suryan70@yahoo.co.id², \\ eddythyap@gmail.com ${ }^{3}$
}

\begin{abstract}
The study is carried out with the objective of examining the effects of bank's liquidity (LR), non-performing loans (NPL), capital adequacy ratio (CAR), loan growth (FEXP) and default risk premium (FQL) on bank's performance as measured by return on assets (ROA) within the framework of Basel Committee on Banking Supervision.The financial intermediation theory of banking is reexamined to see how the current banking supervision safeguards the interest of depositors. Engaging pooled OLS as an estimation tool on 93 commercial banks in Middle East, Africa and Indian subcontinent over study period from 2009 through 2016, the findings reveal thatthere are significant relationships between bank's performance and its liquidity plus loan growth. Both ROA and FEXP are also found to be positively correlated. Even though NPL and CAR do not have significant relationship with ROA, both are found to be negatively correlated with ROA. Overall, the study has proven that liquidity and loan growth have pivotal roles in sustaining bank's profitability over time.
\end{abstract}

Keywords: Bank's Liquidity, Return on Assets, Capital Adequacy Ratio, Non-Performing Loans, Loan Growth, Static Panel Data, PooledOLS and Basel Committee on Banking Supervision.

\section{A. INTRODUCTION}

It is generally known that a banking business is associated with high level of risk with great possibility of insolvency. As such, many agree that banking is one of the most regulated industries in the world (Chortareas, Girardone and Ventouri, 
2012). The 2008 global financial crisis has resulted in significant reforms in banking regulation and today's banking supervision plays an even more important role on the stability of the banking system than before. One must also note that the Asian Financial Crisis in July 1997 not only exerted tremendous impact on the financial well-being of Asian financial institutions, but also on large multinational companies partly owned by government such as Maybank, Samsung and Hyundai.

To begin with, it is essential to give a clear definition of what regulation and supervision mean. The term regulation refers to the setting of the particular principles that firms or banks need to comply to. These might be a set of laws, rules or legislation stipulated by the appropriate regulatory agency. On the other hand, supervision involves the monitoring of the behavior of financial institutions and banks (Casu, Girardone and Molyneux, 2004). This means that the main difference between banking regulation and supervision is that the former focuses on the stipulated rules while the latter involves actual implementation of those rules and regulations. No doubt that regulation and supervision are important because of the risky business nature of banking as advocated by the dominant financial intermediation theory of banking. This theory specifically explains that modern banks collect deposits and later lend them out, exploiting the spread between the deposits and lending rates.

A myriad of studies on banking soundness have been concentrating more on developed countries rather than developing countries and Sub-Saharan Africa (SSA) is no exception. Most of the empirical evidencesare derived from cases in United States and Europe. There is, therefore,a lack of sufficient information on determinants of bank performance in Africa and middle-east which warrant further investigation (Short, 1979; Bourke, 1989; Molyneux and Thornton, I992; Demerguc-Kunt and Huizinga, 200I).Interestingly, there have been no serious problems reported on those banks in Middle East, Africa and Indian subcontinent after the 2008 global financial crisis. This paper attempts to provide useful insights on the soundness of the banking system in this region.

\section{B. THEORITICAL}

Despite significant reforms made in the financial sector in Sub-Saharan Africa during 1980 and 1990, financial depth in this sub-region still remained low and has not been improving over the years. Poor performance of banks are attributed to low levels of private credit, high interest rate spreads, high levels of non-performing loans, poor asset quality and operational inefficiencies(Panayiotis, et al., 2005). 
For every bank, its strength and resilience may come from within or outside the bank itself. Mercia, et al. (2002), Toddard, et al. (2004), and Panayiotis, et al. (2005) argue that bank's profitability is subject to internal and external factors. Internal factors involve bank-specific variables; while external factors include both industry-specific and macroeconomic factors. Literature suggests that there are six standard key bank-specific indicators which are commonly used to investigate bank soundness. Those are bank's profitability, capital adequacy, asset quality, operational efficiency, and growth in bank assets. Meanwhile, industry-specific factors comprise of ownership, bank concentration index.Lastly, the macroeconomic factors consider interest rate, interest rate spread, inflation rate and the rate of economic growth as measured by annual GDP.

As the main purpose of this paper is to investigate bank's long-term sustainability, it is very important to have a specific measurement of the bank's soundness and robustness. The liquidity coverage ratio (LCR) is an important part of the Basel Accords, as they dictate the amount of liquid assets required to be retained by financial institutions. As banks are required to hold a certain level of highly liquid assets, they are less likely to be able to provide short-term lending (Francis, 20I3).This study is narrowed down towards a number of pertinent issues within Basel risk management framework. Liquidity ratio (LR), capital adequacy ratio (CAR), non-performing loans (NPL) and default risk premium (FQL) are used as proxies for bank's soundness, while loan growth (FEXP) is a measure for bank's robustness.Subsequently, the following research questions are studied and analyzed:

I. Did LR and CAR really exert significant influence on bank's profitability?

2. Is there any significant relationship between loan growth (FEXP) and bank's profitability?

3. Is there a strong correlation between loan growth (FEXP) and bank's NPL?

The World Bank (2006) acknowledges that there are only few signs of sustainable progress arising from both public and financial sectors. The report has called for more comprehensive reforms not only in the financial sector but also in the public services. Banks are important players in the financial system and therefore they must operate at the optimal level of efficiency in the banking sector. Bank efficiency results in growth in quality assets that this is the key enabler that supportseconomic growth in the different segments of the economy. 


\section{B. METHODOLOGY}

I. Data

This study attempts to uncover the theoretical link between bank's profitability and its asset classes (liquid assets and new loans). The study also looks into the effect of poor asset quality (NPL and default loans) on bank's long-run profitability. Analysing the yearly data from year 2009 through 2016, the study examinesfinancial data from 93 banksacross Middle East, Africa and Indian subcontinent. All secondary data are obtained from World Bank database. The bank-specific factors are expressed as follows:

I. LR =Liquidity Coverage Ratio=Total of Highly Liquid Assets/Total Assets (in \%)

2. $\mathrm{FQL}=$ Default Risk Premium $=$ Total Amount of Default Loans $/$ Total Loans (in \%)

3. FEXP $=$ Loan Growth $\%=$ New Loan Created/Total Assets (in \%)

4. NPL $=$ Amount of Non-Performing Loans/Total Loans (in \%)

5. $\mathrm{CAR}=$ Capital Adequacy Ratio=Total Paid-up Capital/Total Loans (in \%)

6. $\mathrm{ROA}=$ Net Profits/Total Assets (in \%)

\section{2 heoretical Framework for Bank Profitability Measurement}

In developing bank's profitability model, this study replicates the work of by Naceur et.al. (2003) and Panayiotis et al. (2005) on Tunisian banks and Greece banks respectively. Based on economic theory, the general functional form of profit efficiency is expressed as follows:

$\prod_{i t}=\alpha+\alpha \mathrm{i} \Sigma \prod_{\mathrm{t}-\mathrm{i}}+\beta \mathrm{iX}$ it + uit

where $\mathrm{i}_{\mathrm{i}}$ is the profitability variable and $\mathrm{Xi}=$ bank-specific factors or profitability determinants, and uit is group specific variation that is time invariant. Empirical theory identifies ROA as a common possible choice for measuring bank profitability.

\section{Model Specification and Variables}

Model specification and variable identification are operationalized in line with Naceur et al. (2003) and Panayiotis et al. (2005) but with little modification. Since this study falls into static panel framework, the pooled OLS regression is employed as a base-line analysis. This study also reduced the number of explanatory variables by incorporating only six factors into the equation: bank's profitability; capital adequacy that measures the bank ability to meet regulated capital standards; default risk premium that measures changes in the bank loan 
quality and risk; loan growth that measures the bank ability to generate revenue; liquidity ratio that measures the changes in the bank cash position; and nonperforming loan that measures the bank's potential liability. Based on these six factors,a regression analysis to estimate bank's profitability model is developed. Deploying the profitability function, the following model specification is postulated:

$\Pi_{\text {it }}={ }_{c}+\beta$ IFEXPit $+\beta 2 C A R$ it $+\beta 3 L$ Rit $+\beta 4 F Q L i t+\beta 5 N P L i t+\varepsilon i t \ldots . . .(2)$

where Iitis profitability variable represented by $R O A, F E X P$ is bank's loan growth, $C A R$ is bank'stotal equity to its total assets, $L R$ is bank's liquidity ratio, FQL is bank's default risk premium and finally $N P L$ is the proxy for bank's nonperforming loans.

Table I presents the variables and expected impact on bank's profitability as demonstrated by earlier researchers (Anthanasoglou et al., 2006) on their studies in developed economies.

\section{Table I: Determinants of banks' profitability and expected impact}

\section{Explanatory variable Expected impact}

Growth in total assets - (FEXP) Positive

Capital adequacy - $(C A R)$ Positive

Liquidity ratio - $(L R)$ Negative

Default risk premium - (FQL)Negative

Non-Performing Loans- (NPL) Positive

\section{RESULTS AND DISCUSSION}

To demonstrate the effect of changes in bank-specific factors on bank's profitability, the empirical results are shown in Table 2, Table 3 and Table 4 respectively. As explained earlier, the pooled OLS procedure is used as an estimation model for this static panel data framework. To begin with, the descriptive statistics and correlation analysis are presented in the following paragraph.

From Table 2, it is evident that the mean ROA for all 93 banks is moderately low at I.8 percent coupled with bank liquidity ratio of 36 percent. On the back of robust loan growth of almost 63 percent (mean growth rate), the mean percentage of non-performing loans is successfully kept below 6\%. The default risk 
Bank Soundness And Sustainability-Evidence From Middle East, Indian Sub-Continent And African Banks

(Abdul Razak Abdul Hadi ${ }^{1}$,Tulus Suryanto ${ }^{2}$,Eddy Yap Tat Hiung ${ }^{3}$ )

premium is also observed settling at low level of mean 2 percent.It is interesting to highlight that the average capital adequacy ratio stands at relatively high level of almost I9 percent, providing solid buffer for bank's entire asset portfolios. These preliminary findings seem credible to support bank soundness in the observed region over 8 years study period. In terms of riskiness, (looking at the degree of dispersion from the mean line), loan growth slightly has lower standard deviation as compared to bank's liquidity ratio.

Table 2

Descriptive Statistics of Bank-Specific Factors

\begin{tabular}{|c|c|c|c|c|c|c|}
\hline Variable & Label & $\mathrm{N}$ & Mean & $\begin{array}{l}\text { Standard } \\
\text { Dev }\end{array}$ & Minimum & Maximum \\
\hline $\mathrm{ROA}$ & return on assets & 744 & 0.0179167 & 0.0208910 & 0 & 0.2100000 \\
\hline NPL & non-performing & 744 & 0.0554973 & 0.0735105 & 0 & 0.6000000 \\
\hline CAR & & 744 & 0.1882796 & 0.1043624 & 0.0700000 & I.8300000 \\
\hline LR & $\begin{array}{c}\text { capital adequacy } \\
\text { ratio }\end{array}$ & 744 & 0.3601613 & 0.2144779 & 0 & 0.9400000 \\
\hline FQL & liquidity ratio & 744 & 0.0206048 & 0.0352348 & 0 & 0.5100000 \\
\hline FEXP & $\begin{array}{l}\text { financial quality } \\
\text { financial expansion }\end{array}$ & 744 & 0.6264785 & 0.2015077 & 0.0100000 & 3.4600000 \\
\hline
\end{tabular}

Table 3 shows the results from Pearson correlation analysis. A hypothesis testing is carried out to determine the significance level of the correlation coefficients. Pvalues are reported, indicating the level of significance.From the statistical output, FEXP has the highest positive correlation (I4\%) with ROA followed by LR ($9.7 \%$ ) and both variables are significant at 5\% level. On contrary, CAR registered the lowest correlation $(-0.9 \%)$ with ROA but it is not statistically significant.

Table 3

Correlation Analysis of Bank-Specific Factors

Pearson Correlation Coefficients, $\mathrm{N}=744$

Prob $>|\mathrm{r}|$ under HO: Rho $=0$ 


\begin{tabular}{|c|c|c|c|c|c|c|}
\hline & $\mathrm{ROA}$ & NPL & CAR & LR & FQL & FEXP \\
\hline ROA & I.00000 & -0.04880 & -0.00967 & -0.09767 & 0.07375 & 0.13902 \\
\hline return on assets & & 0.1837 & 0.7923 & 0.0077 & 0.0443 & $0.000 \mathrm{I}$ \\
\hline NPL & -0.04880 & 1.00000 & 0.00262 & -0.04586 & -0.02420 & 0.00174 \\
\hline non-performing loans & 0.1837 & & $0.943 \mathrm{I}$ & 0.2115 & 0.5098 & $0.962 \mathrm{I}$ \\
\hline CAR & -0.00967 & 0.00262 & 1.00000 & -0.05486 & -0.02644 & -0.17062 \\
\hline capital adequacy ratio & 0.7923 & $0.943 \mathrm{I}$ & & 0.1349 & 0.4715 & $<.000 \mathrm{I}$ \\
\hline LR & -0.09767 & -0.04586 & -0.05486 & 1.00000 & 0.00444 & -0.09189 \\
\hline liquidity ratio & 0.0077 & $0.2 \mathrm{II} 5$ & 0.1349 & & 0.9038 & 0.0122 \\
\hline FQL & 0.07375 & -0.02420 & -0.02644 & 0.00444 & I.00000 & 0.04568 \\
\hline financial quality & 0.0443 & 0.5098 & 0.4715 & 0.9038 & & 0.2133 \\
\hline FEXP & 0.13902 & 0.00174 & -0.17062 & -0.09189 & 0.04568 & 1.00000 \\
\hline financial expansion & $0.000 \mathrm{I}$ & $0.962 \mathrm{I}$ & $<.000 \mathrm{I}$ & 0.0122 & 0.2133 & \\
\hline
\end{tabular}

The empirical results from pooled OLS regression in Table 4 indicate an acceptance of alternative hypothesis for two bank-specific variables - LR and FEXP. This findingimplies that there are statistically significant relationship between them and bank's profitability as measured by ROA. Consistent with the findings of earlier studies (refer Table I), both LR and ROA have a significant negative relationship. As for FEXP, its relationship with ROA is found to be significantly positive. Looking at the fit statistics in Table 5, the low $\mathrm{R}^{2}$ of $3.4 \%$ does not warrant a desirable goodness of fit for this estimated model.However, this is not a pressing issue as low $\mathrm{R}^{2}$ is normally expected in panel data regression. Nevertheless, a more robust static panel data model like random effects or fixed effects needs to be considered. 
Bank Soundness And Sustainability-Evidence From Middle East, Indian Sub-Continent And African Banks

(Abdul Razak Abdul Hadi ${ }^{1}$,Tulus Suryanto²,Eddy Yap Tat Hiung ${ }^{3}$ )

\section{Table 4}

\section{Pooled OLS Analysis}

$\mathrm{H}_{0}$ : Absence of significant relationship between Profitability and Bank-Specific Factors

$\mathrm{H}_{\mathrm{I}}$ : Existence of significant relationship between Profitability and Bank-Specific Factors

\begin{tabular}{|c|c|c|c|c|c|c||}
\hline \multicolumn{7}{|c|}{ Parameter Estimates } \\
\hline \hline Variable & DF & Estimate & $\begin{array}{c}\text { Standard } \\
\text { Error }\end{array}$ & $\mathrm{t}$ Value & $\operatorname{Pr}>|\mathrm{t}|$ & Label \\
\hline \hline Intercept & $\mathrm{I}$ & $0.0122 \mathrm{I} 4$ & 0.00353 & 3.46 & 0.0006 & Intercept \\
\hline \hline NPL & $\mathrm{I}$ & -0.01462 & 0.0103 & $-\mathrm{I} .42$ & 0.1560 & $\begin{array}{c}\text { non-performing } \\
\text { loan }\end{array}$ \\
\hline \hline CAR & $\mathrm{I}$ & 0.001908 & 0.00737 & 0.26 & 0.7958 & $\begin{array}{c}\text { capital adequacy } \\
\text { ratio }\end{array}$ \\
\hline \hline LR & $\mathrm{I}$ & -0.00856 & 0.00355 & $-2.4 \mathrm{I}$ & $0.0162^{*}$ & liquidity ratio \\
\hline \hline FQL & $\mathrm{I}$ & 0.039862 & $0.02 \mathrm{I} 5$ & $\mathrm{I} .86$ & 0.0639 & financial quality \\
\hline \hline FEXP & $\mathrm{I}$ & 0.013435 & 0.00383 & $3.5 \mathrm{I}$ & $0.0005^{* *}$ & $\begin{array}{c}\text { financial } \\
\text { expansion }\end{array}$ \\
\hline \hline
\end{tabular}

Table5

Fit Statistics of Pooled OLS Model

\begin{tabular}{|c|c|c|c|}
\hline \hline \multicolumn{4}{|c|}{ Fit Statistics } \\
\hline \hline SSE & 0.3133 & DFE & 738 \\
\hline \hline MSE & 0.0004 & Root MSE & 0.0206 \\
\hline \hline R-Square & 0.0340 & & \\
\hline \hline
\end{tabular}




\section{CONCLUSION}

From the empirical results of pooled OLS regression, there arestatistically significantrelationship between bank's profitability and its liquidity ratio as well as loan growth.As such, it is worth noting that bank's liquid assets significantly influence bank's profitability and therefore any change in central bank's policy that promotes reduction in bank's liquidity requirement is seen timely and favorable to the bank management.Effective liquidity risk management helps ensure a bank's ability to meet cash flow obligations, which are uncertain as they are affected by external events and other agents' behaviour. As anticipated, liquidity ratio is found to be negatively correlated with bank's profitability, while loan growth and bank's ROA are positively correlated. This study also reveals that both NPL and CAR are negatively correlated with ROA, suggesting that any percentage increase in these two variables will exert some detrimental effect on bank's long-run profitability.However, these two variables do not have statistically significant relationship with ROA.Being a financial intermediary, every bank must safeguard the margin of safety between their customers' deposits and loanable funds. It is hoped that the bank's top management would understand the important interactions between bank's profitability and its specific factors, particularly liquidity management and loan growth (Francis, 20I3).Every manager undoubtedly works to maximize shareholders' wealth but ultimately one must strike the balance between bank soundness and its sustainability in the long-run.

\section{REFERENCES}

Anthanasoglou, P., Delis, M., \&Staikouras, C. (2006).Determinants of banking profitability in South EasternEuropean region.Bank of Greece Working Paper, 06/07.

Bourke, P. (I989). Concentration and other determinants of bank profitability in Europe, North America andAustralia.Journal of Banking and Finance, I3, 65-79. http://dx.doi.org/I0.I0I6/0378-4266(89)90020-4

Casu, B., Girardone, C., \&Molyneux, P. (2004).Productivity change in European banking: A comparison of parametric and non-parametric approaches. Journal of Banking \& Finance 28 (I0), 252I-2540.

Chortareas, G., Girardone, C., \&Ventouri, A. (20I2). Bank supervision, regulation and efficiency: Evidence from the European Union. Journal of Financial Stability, 8(4), 292-302.

Demerguc-Kunt, A., \& Huizinga, H. (200I). Financial structure and bank profitability in financial structure andeconomic growth: A cross-country

https://ejournal.radenintan.ac.id/index.php/ikonomika 
comparison of banks, markets and development. In AsliDermirgue-Kunt,\& Rose, L. (Eds).Cambridge, MA: MIT Press.

Francis, M.E. (2013). Determinants of Commercial Bank Profitability in SubSaharan Africa.International Journal of Economics and Finance, 5(9), I34-I47. http://dx.doi.org/I0.5539/ijef.v5n9pI34

Mercia, M. C., Evren, O., \& Hassan, T. (2002). Bank performance around the introduction of subsidiary banks inthe US. Journal of Banking and Finance, I7, 389-40.

Molyneux, P., \& Thornton, J. (1992). The determinants of European bank profitability. Journal of Banking andFinance, I6, II73-II78. http://dx.doi.org/I0.1016/0378-4266(92)90065-8

Naceur, A. B., Steiner, R., \&Goaied, M. (2003). The determinants of the Tunisian banking industry profitability:Panel evidence. ERF Research Fellow.

Panayiotis, P., Anthanasoglou, S., Brissimis, N., \&Mathaios, D. D. (2005).Bank specific, industry-specific andmacroeconomic determinants of bank profitability.Bank of Greece Working Paper, 25.

Short, T. (1979). Monitoring the macroeconomic determinants of banking system stability.Journal of Bankingand Finance, I7(2), I I7-I37.

Toddard, J., Molyneux, P., \& Wilson, J. O. S. (2004).Dynamics of growth and profitability in banking.Journalof Money, Credit, and Banking, 36(6).

World Bank (WB). (2006). Global monitoring report 2005.Millennium Development Goals:From Consensus toMomentum (Washington). 